Article

\title{
Intergenerational Entrepreneurship to Foster Sustainable Development: A Methodological Training Proposal
}

\author{
Adriana Perez-Encinas*(D), Isidro de Pablo, Yolanda Bueno (D) and Begoña Santos \\ Department of Business Organization, Faculty of Economics and Business, Universidad Autónoma de Madrid, \\ Ctra Colmenar Viejo km 15, 28049 Madrid, Spain; isidro.de.pablo@uam.es (I.d.P.); yolanda.bueno@uam.es (Y.B.); \\ begonna.santos@uam.es (B.S.) \\ * Correspondence: adriana.perez.encinas@uam.es; Tel.: +34-605-16-34-85
}

Citation: Perez-Encinas, A.; de Pablo, I.; Bueno, Y.; Santos, B.

Intergenerational Entrepreneurship to Foster Sustainable Development: A Methodological Training Proposal. Sustainability 2021, 13, 9654 https://doi.org/10.3390/su13179654

Academic Editor: Mário José

Baptista Franco

Received: 26 July 2021

Accepted: 24 August 2021

Published: 27 August 2021

Publisher's Note: MDPI stays neutral with regard to jurisdictional claims in published maps and institutional affiliations.

Copyright: (c) 2021 by the authors. Licensee MDPI, Basel, Switzerland. This article is an open access article distributed under the terms and conditions of the Creative Commons Attribution (CC BY) license (https:// creativecommons.org/licenses/by/ $4.0 /)$.
Abstract: Intergenerational entrepreneurial initiatives are aimed at addressing the needs and opportunities of certain social groups and have the potential of becoming successful business projects. Moreover, they are a key to undertake sustainability practices that may represent a competitive advantage for the companies and an example to imitate when creating businesses. The objective of the study is to propose an intergenerational training methodology so that young people and seniors can create companies together, generating social cohesion and sustainable development in response to generational challenges. Intergenerational entrepreneurship seems to be a novel research area, especially when referring to developing methodologies of collaborative entrepreneurship projects. For this purpose, our literature review focuses on, first, the matching theories and experiences applied for intergenerational cooperation; then, literature about training methodologies for entrepreneurship is reviewed; finally, the main theories on training skills for entrepreneurship are approached. Focus groups were conducted as they serve as the main sources of data and are very appropriate for the generation of new ideas within a social context. In general, results show that, for achieving a successful intergenerational cooperation, some specific training is needed for both generations. This paper is a starting point for future research approaching intergenerational entrepreneurship, or entrepreneurial initiatives with singular characteristics, such as rural contexts or people with disabilities.

Keywords: intergenerational entrepreneurship; social innovation; sustainable entrepreneurship; sustainable training methodology; senior entrepreneurship; young entrepreneurship

\section{Introduction}

Sustainable development as a concept emerged in the 1970s and, according to the World Commission on Environment and Development, can be defined as "the economic process that meets the needs of present generations without compromising that of future generations, ensuring a balance between economic growth, environmental care and social welfare" [1]. Despite the differences in socio-cultural, economic, and environmental factors between regions and countries, there is a common need to move from an unsustainable production model to a sustainable and equitable one [2,3]. It is a global challenge that since 2015 has been reflected in the agenda of the United Nations by the adoption of the Sustainable Development Goals and driven by UNESCO, which promotes programs to strengthen education, lifelong learning, mobilize knowledge for sustainable development, and to address social problems to build inclusive knowledge societies, among many others. (https:/ / en.unesco.org/sustainabledevelopmentgoals accessed on 25 July 2021).

Fostering entrepreneurship in this scenario can contribute to fostering sustainable development, if it is based on premises such as social cohesion, education in values, integrating knowledge, addressing social problems, promoting local development and social welfare, etc., giving rise to the sustainable entrepreneurship approach. Thus, sustainable entrepreneurship is understood as "the process of discovering, evaluating, and exploiting 
economic opportunities that are present in market failures which detract from sustainability, including those that are environmentally relevant" [4,5].

This kind of entrepreneurship aims to respond to economic and social challenges, may or may not have a profit-making purpose, adopts social and/or environmental goals, and directly or indirectly contributes to the development of the territory and the community. Therefore, it is an approach to entrepreneurship based on social innovation that incorporates the philosophy of sustainability from the beginning of the project and not only has a for-profit purpose, but also a social and environmental one [6].

Entrepreneurship as an instrument of social innovation promotes growth and development through the efforts of different actors and the use of their capacities and resources, responding to market failures $[7,8]$ and thus matching unsatisfied needs detected in the market and/or closing employment gaps [9].

In this paper, we focus our attention on two social groups with problems of professional insertion-seniors and young people and their limitations for entrepreneurship, despite their undoubted capabilities.

Senior entrepreneurship is understood as a way of solving social and economic problems of an ageing population [10] as seniors would stay in the labor force and may generate economic growth [11,12]. In recent years, senior entrepreneurship has been studied from different perspectives internationally [13-15], and the contributions to the literature differ from a social identity theory perspective and the unemployment of senior people $[16,17]$ to a European policy analysis view for senior entrepreneurs [18], or to the definition of territories to map the strongest regions of the world concerning senior entrepreneurs [19]. Other studies have been focusing on the main obstacles that this population group overcomes $[20,21]$ and the motivations, skills, and opportunities for this group [17,22-24]. Senior people, in addition to increasing their share in total population in most societies, accumulate a very valuable load of experience and maturity that any changing society should consider putting into value. On the contrary, young entrepreneurs are usually people seeking for a job or a professional opportunity as entrepreneur, but lack the experience, contacts, and resources to take up such a deal.

Considering the social inequality, unemployment, vulnerability, and exclusion of these two minorities, we believe that intergenerational entrepreneurship can be a solution for sustainable socioeconomic development. As in other associative and cultural activities, intergenerational cooperation in entrepreneurship can contribute to alleviate inequalities and overcome social segregation, contributing to the development of societies [25]. In fact, intergenerational practice enhances social cohesion, increases understanding between generations and can improve participation in community development [26]. In addition, it is intrinsically a sustainable way of entrepreneurship since it focusses on addressing generational challenges through the creation of value by encouraging social and economic prosperity, thus advancing towards a solidary and integrated society for everyone [27].

However, beyond those business initiatives addressing specific market needs, sustainable intergenerational entrepreneurship may not happen spontaneously. The evidence on intergenerational projects is almost always related to social, solidarity, or local development projects that are not profit-oriented. The succession in family businesses-related to consolidated projects-where several generations converge has also attracted attention, but family businesses are not within the scope of our research [28,29].

Therefore, there is a potential for young and senior collectives complementing each other in terms of their financial and knowledge contribution, life circumstances, and networks, among others, meaning that favorable factors for one group can represent blocking factors for the other, giving place to positive synergies for an intergenerational match [22].

Nevertheless, it is not common to find intergenerational sustainable entrepreneurial projects that provide social value and progress. Even less evidence is found on the entrepreneurial stage, with the convergence of promoters of different generations benefit- 
ing from the synergies generated when consolidating promoter groups leading successful projects.

It is at this point where we believe that our work can provide a framework model that allows the generations to meet, to value the contribution of each one of them to a common project, to generate bonds and to consolidate them as promoters of successful business projects that contribute to local development.

However, as mentioned above, aligning the two generational groups towards a common project may not happen spontaneously. A third key element is required: a specific institutional environment that provides legal and political legitimation, as well as the necessary infrastructures, resources, knowledge, and the networking capability to achieve the program's continuity through time. That is to say, it is necessary to have a driving and hosting organization that delivers the conditions and means with which intergenerational entrepreneurial projects will be promoted in a given community or territory. It is this organization who oversees running the matching and training program for intergenerational entrepreneurs. This requirement is critical if the program is to be run on a long-term basis, with many cohorts and encompassing different sectors of activity.

This step will require the participation of different agents of the entrepreneurial ecosystem and civil society (universities, businesspersons, NGOs, local or regional administration, financial entities, etc.) acting as stakeholders. These bodies, based on a cooperative model related to the Triple Helix, provide support to the managing entity (usually a foundation or non-profit association) of the program during the necessary time until its consolidation $[30,31]$. There is some similar experience in other socioeconomic contexts and focused on other groups that have succeeded in rooting self-employment in their culture [32].

In any case, all this organizational and resource effort must be aimed at developing and implementing intervention methodologies that take advantage of the potential complementarities between generations, and at fostering and consolidating an entrepreneurial spirit based on reciprocity, trust, and social cohesion. This is not easy to accomplish without an adequate educational environment applying the proper objectives, methods, tools, and resources [33]. Nowadays, many young people have difficulties entering the labor market, and older people have obstacles in adapting to a new work environment. This raises questions about whether young and senior people are being well trained for real work situations. Intergenerational education can be effective in bridging the gap between formal education and the skills needed in the labor market [34].

In this regard, Rashid [33], in her study about entrepreneurship education and sustainable development, found a shortage of research on entrepreneurship education and training focused on innovative and sustainable entrepreneurship. Furthermore, she found that minorities are seldom mentioned in research on entrepreneurship education.

Thus, the relevance of this project lies on the evidence of the potential value added by young and senior entrepreneurs teaming up [15] and the significant complementarities both groups have to boost intergenerational cooperation and promote social inclusion [22]. Based on our previous arguments, the objective of this study is to propose an intergenerational training methodology to support young people and seniors create companies together, thus fostering social cohesion and sustainable development.

Thus, the main objectives of this paper are:

- Q1: How to encourage potential young and senior entrepreneurs to collaborate to develop a viable and sustainable business project?

- Q2: What direction and content a training methodology should be taken to generate strong synergies for sustainable business projects?

- Q3: Which hard and soft skills should be developed, and in what stage of the business process?

This study provides a useful reference for civil society organizations, universities, local governments and business organizations, and sensitive NGOs that wish to generate effective business synergies among different vulnerable groups in order to achieve sustainable and inclusive solutions. 
The data presented in this paper come from a European project on promoting the intergenerational entrepreneurship among potential young and senior entrepreneurs, in which three universities working with young populations and three NGOs that are working with the elderly populations in Spain, Sweden, and France are participating. Focus groups is the methodological approach used to understand the needs of young and senior entrepreneurs, being the basis over which the training methodology is developed.

The rest of the paper is structured as follows. First, a literature review is presented that collects the most relevant experiences found in terms of training methodologies for entrepreneurship and delves into the theories that back up the fundamental elements that the methodology should have. The next section describes the methodological approach. Afterwards, the results are discussed, and a methodological proposal is presented. The study ends with the implications of the main findings and the concluding remarks.

\section{Literature Review}

The literature review is presented in three blocks: first, the matching systems theories and experiences are presented; then, literature about entrepreneurship training methodologies are reviewed; finally, the main theories on skills regarding entrepreneurship are studied. All this information will be the basis of the theoretical framework for the training methodological proposal on intergenerational entrepreneurship developed in this research paper.

\subsection{Previous Matching for Intergenerational Business Teams}

To promote sustainable and successful intergenerational teams, it is necessary to achieve an effective match between potential entrepreneurs. People-to-people matching systems (or matching systems) are used in many familiar situations and refer to those in which users come together for the purpose of meeting other users with a common need: employer-employee (in job search networks), mentor-student (in university social networks), consumer-consumer (in marketplaces), and online dating. The network underlying these systems consists of two groups of users, and it is necessary to capture the relationships between them in order to develop an effective matching system. There are systems that use implicit and explicit information from users [35] and there are those that rely on graphs [36].

Matching experiences focused on entrepreneurship seek to link mentors with entrepreneurs, investors with entrepreneurs, or entrepreneurs with each other, but rarely refer to systems that enable this intergenerational matching.

The matching of mentors with entrepreneurs is relevant, as Walmsley and Nabi [37] refer to the importance of properly matching senior entrepreneurs with mentors. Jordan and Sorell [38] also agree that the right match is crucial: "First, emphasize diversity, matching across regions, districts, and locations. Also match for diverse personalities (e.g., it is better to have an introvert paired with an extravert than to pair two introverts). Second, consult mentees before making the pairing formal. While most Millennial mentors accepted any pairing (as long as the mentee was committed), executive mentees were more selective, as they were concerned about crossing supervisory lines and any appearance of conflict of interest".

In matching entrepreneurs with investors, there is a protocol for matching entrepreneurs and business angels [39] and other models that match entrepreneurs with investors in general [40-42].

Regarding the last case that relates entrepreneurs to each other, and these being the most relevant systems for the purpose of the research, there is a proposal for regional development strategies by the EU [43], proposing to consider this matching as a collaborative model [44]. The activity carried out by TIGcRE [45] with the intelli7 [46] system in which senior and junior entrepreneurs are matched is noteworthy; in this experience, carried out in France, TIGcRE assists entrepreneurs during the process to facilitate the business's success. 


\subsection{Training Methodologies in Entrepreneurship}

Entrepreneurship training has been gradually incorporated into educational curricula in recent decades. Although this fact is no longer something new, in these times of economic, political, social, and educational crisis, entrepreneurship is considered a fundamental lever for change, and it is being promoted at all educational levels. In the last decades, it was thought that certain facets of entrepreneurship could not be taught [47] including personality issues and considering that entrepreneurial competencies can be taught and learned in different places and ways [47-50].

From a broad perspective, entrepreneurship training programs can be reduced to two distinct situations [51]: those oriented to facilitate "entrepreneurial learning" (EL) of people with entrepreneurial intentions, and characterized, therefore, by an immediate orientation to practice, and, on the other hand "entrepreneurship education" (EE), with entrepreneurship contents incorporated in academic programs, from secondary education to university postgraduate, completing the curricular content, whether general or specialized, with entrepreneurship content in the event that participants have the opportunity to create their own entrepreneurial project and have a foundation with which to approach it. EL focuses on the entrepreneur himself, while EE focuses on the teacher, who teaches curricular content to a class in which students interested in entrepreneurship may be a minority.

Due to the formalism of academic programs [47], EE has been analyzed more than EL [52,53], although many researchers have marked a significant lack of studies on the outcomes and effectiveness of EE programs [54]. It has taken several years to investigate how real entrepreneurs learn and acquire the competencies they need for their activity [55] along the entrepreneurial roadmap presented by Ndou, Secundo, Schiuma, and Passiante [56] that a potential entrepreneur would follow from the initial vocational phase to the managerial phase in which the project is running smoothly. Morris, Webb, $\mathrm{Fu}$, and Shinghal [55] identify a series of generic competencies-grouped around four categories: technical knowledge, skills, attitudes, and behaviors-that characterize the training of potential entrepreneurs, which they identify as opportunity detection and assessment, risk management, creative problem solving, value creation and building, and network management.

While conventional EE focuses more on technical knowledge, EL focuses on the development of competencies through the active learning approach (learning by doing), management of contingencies and unforeseen situations [57], management of failure [58], reflection based on own and others' experience [59], problem-solving skills, self-confidence, and reflection [60]. It follows that active learning is more effective in entrepreneurship training regardless of the target of the program, a student, or an entrepreneur, because, after all, everyone has the same learning capacity [61].

In addition, it is worth considering that there are two approaches in which entrepreneurial education is contextualized. The first understands the entrepreneurial process as a causal or constructive approach $[62,63]$. This goal-oriented approach is viable with a familiar environment, an opportunity is envisioned, goals are set, a plan is drawn, and resources are sought to achieve them. It is therefore based on the logic of prediction. It is the most widespread model because it relies on the use of secondary information and is easy to teach [64]. The "Business Plan" method is its main reference.

However, technological, economic, and social changes have led to the emergence of new professions and business model proposals, often without any reference to analyze in the market. In this scenario of uncertainty, the causal model is not the most appropriate due to the lack of references with which to formulate the hypotheses that support the predictions.

Sarasvathy [62] points out that entrepreneurs do not always start their entrepreneurial adventure with a clear and defined idea of their business project, but rather they begin with the generic will to create a new company, and based on interactions with various stakeholders, they build their business proposal. This is another way of understanding 
entrepreneurship, since the reality of new companies in unpredictable scenarios follows an "effectuation" logic.

Effectuation is the opposite of causality. It is based on a logic of controlling the future when predictions cannot be made. Sarasvathy [62] has proposed effectuation as the dominant decision model for business decision making, particularly in the absence of pre-existing markets. It involves hypothesizing and testing hypotheses and requires attempts to shape and create the potential market.

It is based on the well-known Lean Start-up methodology of Eric Ries [65], the result of several methodologies such as Design Thinking, Lean Manufacturing and Agile, which proposes validated learning. That is, starting from a design that materializes in a "minimum viable product" that requires less investment and its acceptance in the market is tested iteratively while improving and adding features in a continuous cycle of learning and validation that refines the viable business model on which the new company will be based.

However, a causal approach or an effectuation logic are not mutually exclusive methodologies, but they are rather different approaches to consider in the process of entrepreneurship.

\subsection{Skills and Entrepreneurial Competencies}

Entrepreneurial training programs and their methodologies are the vehicle for developing entrepreneurial competencies. Their main objectives are, firstly, technical capacity to design an entrepreneurial project; and secondly, to provide a set of entrepreneurial skills and attitudes that reinforce the primary objective [66]. According to specialized literature, the most effective means for the development of entrepreneurial competence are based on active learning, i.e., on the protagonism of the learner-entrepreneur rather than those centered on the teacher $[60,67,68]$.

The most common means of this training approach include the following: scenario simulation, role-playing and real management experiences [69], and the discussion of case studies and business simulations [70]; all complemented by the development of realistic entrepreneurial projects that combine traditional teaching with sessions with entrepreneurs [71], cross-appraisals by peers, primary information gathering and open discussions on thematic proposals [70]. In short, the aim is to create a context in which program participants learn, exercise, and strengthen their entrepreneurial skills constructed upon active learning resources.

Based on an extensive documentary review, Azim and Al-Kahtani [66] show a broad catalog of the usual training objectives in entrepreneurship programs, ranging from the usual technical content in a business plan, to a set of competencies (skills, behaviors, and attitudes) that make a person unique, that is, those related to idea generation, team building, business planning, inspiration, creativity and innovation, opportunity recognition, selling, network management, adapting to change, resolving contingencies, and accepting failure [72,73]. This set of competencies is referred to as soft skills, and it is to be expected [74] that, at each stage of the entrepreneurial process-defining the idea, developing the business model, and launching it-different skills are required on a cumulative basis.

According to [75] Chell (2013), these skills can be classified into the following general categories:

- Innovation and the creative capacity to visualize opportunities and generate new business ideas and foresight the future [76-79];

- $\quad$ Leadership skills, interpersonal skills, and the ability to manage people [80,81];

- $\quad$ Ability to recognize market opportunities. [77,82-86];

- $\quad$ Risk-taking and the ability to manage conflict $[87,88]$;

- Ability to integrate socially and to network [77,80,89];

- Adaptation to change [90-92];

- $\quad$ Resilience and ability to handle difficult situations $[77,89,93,94]$.

The selection of the most appropriate ones for an entrepreneurship training program, and how they work, is beyond the scope of this research. 


\section{Materials and Methods}

The objective of the paper is to propose an intergenerational training methodology so that young people and seniors create companies together, thus generating social cohesion and sustainable development. This research focuses on understanding how to accomplish it, what direction should the training methodology should take, and which hard and soft skills are required in each stage of the business creation process.

For this purpose, a qualitative methodology was chosen, as focus groups are very appropriate for the generation of new ideas formed within a social context $[95,96]$ and capitalize on communication between participants to generate data. In fact, qualitative research is becoming increasingly popular in organizational studies and contributes positively to the diversity of academic inquiry in entrepreneurship [97].

The main reason to use this qualitative methodology was to identify the skills required by young and senior entrepreneurs along the entrepreneurial process and to design a training methodology that will enhance and promote potential collaboration between both groups. Moreover, focus groups allow for capturing specific information of the participants context, giving valuable information of how entrepreneurship between young and senior entrepreneurs can foster sustainability. However, focus groups as research method can be hard to manage and difficult to encourage people to participate in [98]. The dataset used in this study comprises information from young and senior entrepreneurs (nine women and nine men) from Spain, Sweden, and France, considering that this research is framed in a European project Erasmus+, with the participation of three universities working with young population and three NGOs working with the elderly populations in the aforementioned countries.

The application of our methodology followed five adapted steps based on the scheme proposed by Powell and Single [99-102] in 1996: (1) the selection of target group, in this case, young and senior entrepreneurs with shared key characteristics pertinent to the study; (2) the creation of a protocol; (3) the establishment of the main topics for discussion, as they can be seen in the figure below; (4) the development of the focus groups in a neutral meeting place where participants sat in a circle, to maximize face-to-face-contact; and finally, (5) the analysis of the information gathered. The aforementioned steps and detailed information on the methodology process and sample are deeper explained in Figure 1:

Thus, the methodology utilized for gathering the perspectives of young and senior entrepreneurs follows a qualitative logic considering the perspectives and opinions of the age groups involved. The discussion centered on the perceptions of both collectives regarding the intergenerational potential for business creation and their skills. 
$\underline{\text { Steps }}$

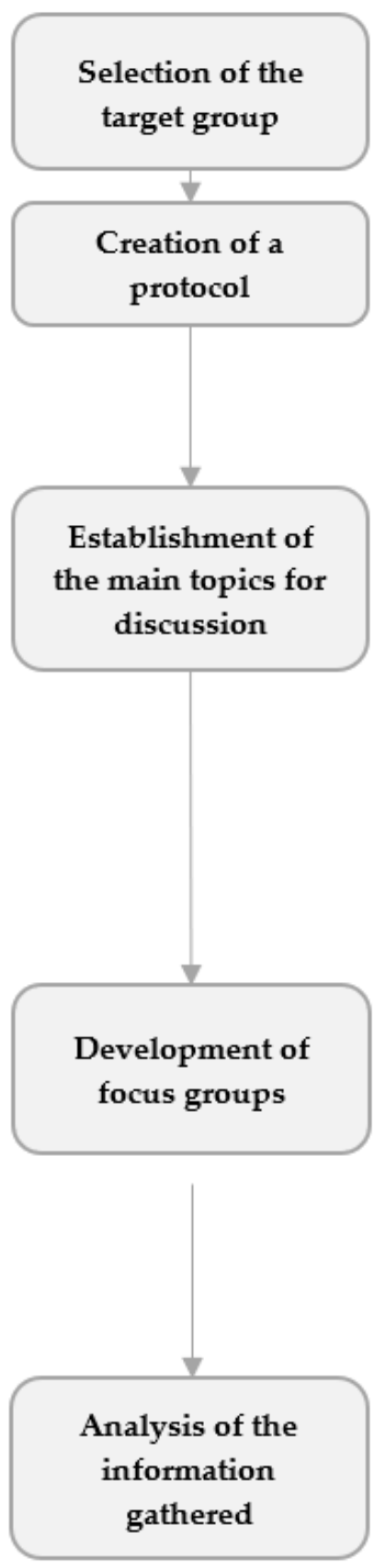

\section{Description}

The first stage consisted of selecting the target group by carefully identifying potential young and senior entrepreneurs and experts in the field.

A panel of experts, young and senior entrepreneurs, from the three countries, designed the focus groups.

7 discussion topics were defined:

- Personal situation

- Professional network

- Perception of the intergenerational aspect of a partnership

- Perception of complementarities between seniors and youngsters

- Perception of the respective roles of each group when managing a common project

- Typical hard and soft skills of each population

- Perception of specific needs identified in terms of skills for each group

This step involved the development of the groups of discussion and a moderator in a particular setting in which the participants felt comfortable enough to engage in a dynamic discussion for one or two hours [100]. Focus groups were done in the three countries.

Each focus group took a maximum of about two hours, 6 focus groups developed with young and senior entrepreneurs, trainers and mentors specialized in entrepreneurship who shared key characteristics pertinent to the study ( $\mathrm{n}=18$ ), nine women and nine men. The discussions were recorded, documented, and transcribed.

A framework analysis was done consisting of familiarization, identifying a thematic framework, indexing, charting, and mapping and interpretation of the data $[101,102]$.

The information gathered in the focus groups was analyzed by a panel of experts and a full report can be provided upon request.

Figure 1. Methodology process. (Source: Designed by authors).

\section{Results}

In general, results show that for achieving a successful intergenerational cooperation considering sustainability throughout the process, training is needed for both senior and young would-be entrepreneurs. Although there is a common understanding of the potential complementarity between young people and seniors to conduct a sustainable and successful entrepreneurial project, an upgrading is needed in different aspects so that the cooperation works well.

During the focus groups, different topics were brought to light. First, for a better intergenerational cooperation, there should be a mix of people proposing ideas for business 
("project holders") with people looking for ideas and projects to join ("skill holders"), whatever the age group they come from. Networking is an important part of the job of an entrepreneur and should be promoted with an intergenerational approach. In addition, this is fundamental for achieving a good intergenerational entrepreneurial experience.

In terms of the skills needed to start a new business, it is critical that people can identify the right profile of soft skills to partner with because, during the group discussions, senior and young participants mentioned the importance of sharing the same passion, teaming up, and being able to fully trust each other.

The methodology applied gives as a result the identification of the main concerns when teaming up intergenerational groups. The discussions centered in the personal situation of each collective, their professional network, their perception of intergenerational entrepreneurship, their complementarities, and their role as team members. In addition, the soft and hard skills needed were pointed out.

In general, seniors expressed a more supporting attitude facing young entrepreneurs, being prone to share experience, contacts, and financial support. However, young people hardly ever mentioned seniors when discussing their project and feared they may have a parental attitude. Seniors perceive those young entrepreneurs can give dynamism to the project and have more relevant technical knowledge. On the other hand, young people recognize that seniors can contribute to the project with their know-how and network.

In terms of skills, young entrepreneurs are more technically well prepared in relation to entrepreneurship, but they lack the experience and emotional management for working with seniors. Furthermore, seniors have a load of experience but need more ICT and digital media training as well as emotional management for working with young people.

Even though there can be complementarities, behavioral tendencies may complicate the favorable convergence of both groups, thus, a common integrative training and coaching methodology on intergenerational entrepreneurship is required to address both groups and facilitate teambuilding. Such methodology should be applied along a wide time lapse to increase its effectiveness based on availability, technical expertise, and confidence.

The above results guide the answer of the first research question:

- Q1: How to encourage potential young and senior entrepreneurs to collaborate to develop a viable and sustainable business project?

Focus groups allowed us to identify three key elements when designing a training program for intergenerational sustainable entrepreneurship. The first one relates to the importance and compromise of the program's stakeholders, that is, the supporting institutions, which can be grouped into two distinct categories: political or social stakeholders, and operational stakeholders. The former includes the promoting bodies, usually local bodies, such as municipalities or regional governments, business associations, and other civil society organizations whose role is to legitimate the project from the social, political, and economic viewpoints. The later refers to educational institutions, usually related to higher education or vocational education and NGOs working with senior people, which are the ones to provide with the participants in the program, that is, the young and senior candidate entrepreneurs, and support the day-to-day operation of the project. Finally, there is the entity (foundation or association) that manages the day-to-day running of the program, makes it grow over time and in new areas of sustainable entrepreneurship in its territory of action.

The second issue raised in the focus group is the contents and learning approach. Thus, the program should have distinct, although integrated, contents: a broad training package in sustainable entrepreneurship embedded in a specialized soft skills package adapted to intergenerational settings, encompassing behavioral aspects, networking, and pitching.

In addition, since the design and deployment of these projects is often multidisciplinary in content and specific to certain technologies, resources, or culture, trainers should be supported by experts in different areas, especially in topics related to sustainability and change management, who then provide support to the participants as tutors or facilitators of their projects and connecting with external resources. Decentralization allows for a better 
cooperation between different sectors and institutions so it should be open to institutional collaboration, whether public, private, or any other kind.

Beyond this general framework, there are specific aspects or principles that should be considered. Since both young and senior potential entrepreneurs show different profiles (educational, socioeconomic, and professional), the training methodology should comply with the following general design principles:

- Both groups show strengths and weaknesses which can be approached with an appropriate integrative training methodology.

- Mutual respect and empathy should be encouraged in group interaction.

- Each group has different needs as to "hard" and "soft" skills, some of which might be worked out separately to avoid damaging comparisons and tensions.

- Soft skills are more transversal and necessary for all team members to acquire and build up team culture.

- Those skills which one group has and can transmit to the other one under a respectful and welcoming atmosphere should be worked together to reinforce mutual understanding, knowledge transmission and social cohesion.

- It is keen to design activities aimed at building and reinforcing mutual respect and value as the basis for effective intergenerational collaboration. These activities must provide a framework in which each group can bring their skills to achieve a common goal via collaboration and need of achievement.

- Intergenerational activities should be durable enough and result-oriented (rewards, recognition, and incentives of any kind) to foster the exchange of feelings, dependability, and team building. This means that each group will have its learning experience with a unique output.

- Not all team members should acquire the same hard skills since there can be, and should be, task specialists within the group.

- Activities oriented to develop sensitivity and knowledge in sustainability are required for both groups.

The way of encouraging potential young and senior entrepreneurs collaborating to develop a viable and sustainable business project is through the design of a training methodology approaching their needs and assets. Once the first research question is answered and the outline of the training methodology is laid down, the second research question arises:

- Q2: What purpose and content should a training methodology take to generate strong synergies for sustainable business projects?

Although there are a good number of field experiences in intergenerational entrepreneurship, very few of them have developed a formal intervention methodology, and even a smaller number share their methodology. Some examples are the project "La Tiendita", promoted by Generations United (https://bit.ly/3iEMGRg accessed on 25 July 2021) to approach social isolation among Latino older aduts; Nittua (http:/ / www.nittua.eu accessed on 25 July 2021), awarded by Ashoka, has created a platform for social change promoting sustainable intergenerational sustainable projects in different fields related to social inclusion, environmental protection, and the solidarity economy; or the Santa María la Real Foundation (https: / / www.santamarialareal.org/es accessed on 25 July 2021) aimed at fostering sustainable social innovation via entrepreneurial projects based on the local cultural heritage and the human and natural resources of the territory.

Based on the previous findings and the evidence from other intergenerational experiences, we have designed a specific training and support methodology for successful intergenerational entrepreneurship. A previous matching effort is assumed as previously described in this paper. Since entrepreneurship implies going through a personal itinerary that each potential entrepreneur should follow, starting with the possibility of becoming an entrepreneur to the desirable state of running a successful project, we understand this itinerary can be broken into five evolutionary phases, each one of them responding to a 
specific goal and requiring a set of hard and soft skills to be worked out at the personal or entrepreneurial team basis. Based on Ndou, Secundo, Schiuma, and Passiante's [56] model, we have developed the general training model (see Figure 2) to gradually foster successful intergenerational projects.

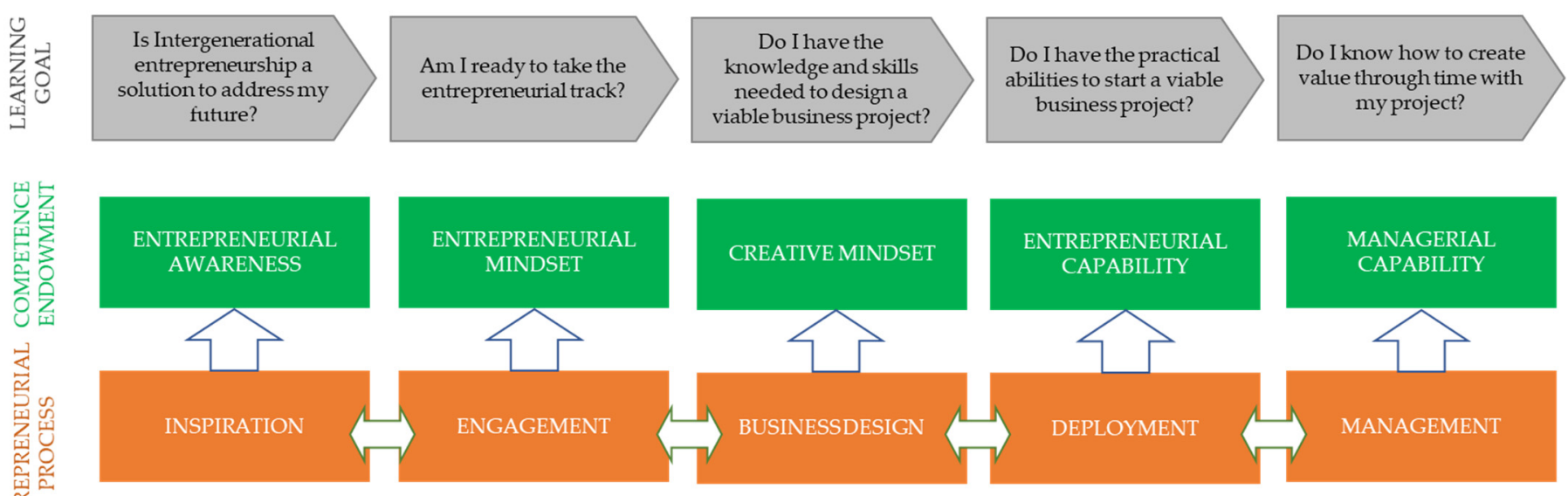

Figure 2. A process-based framework for training skills in intergenerational entrepreneurship. (Source: Based on Ndou, Secundo, Schiuma, and Passiante [56]).

Each phase of the process responds to a learning purpose and is aimed at working with the necessary skills (both soft and hard) to attain such goal with a practice-oriented program.

The process flows along the following phases:

- Inspiration: in which the participants, both young and senior, approach the option to take entrepreneurship as a lead line for their future;

- Engagement: aimed at developing the basic hard and soft skills-basically a technical knowledge, networking, analysis, and group dynamics-needed to start the entrepreneurial track under a "make up your mind" approach;

- Business Design: related to outlining and defining the business idea and managing the entrepreneurial team to design a road map justifying the project's viability before putting it into practice under the "look before you leap" approach;

- Deployment: aimed at the implementation and management of all the new company's processes involved with everyday operations-marketing and sales, operations, financing, administrative, people, legal and tax issues, sustainability, etc.;

- Management: related to the issues affecting everyday operations once the company is under course, and the future evolution of the new firm, such as scenario analysis, goal orientation, strategic management, etc., and eventually, the sale or discontinuity of the business under future circumstances. This phase is a rather open-end situation in which the entrepreneurial experience may be very far behind for the protagonists.

Throughout this step-by-step approach, both hard and soft skills must be worked out to provide participants with the technical, intellectual, and social levers they need to develop their projects in the appropriate context in which they may be necessary.

Figure 3 depicts the overall vision of how the proposed methodology responds to the challenges imposed by each phase in the training program. 


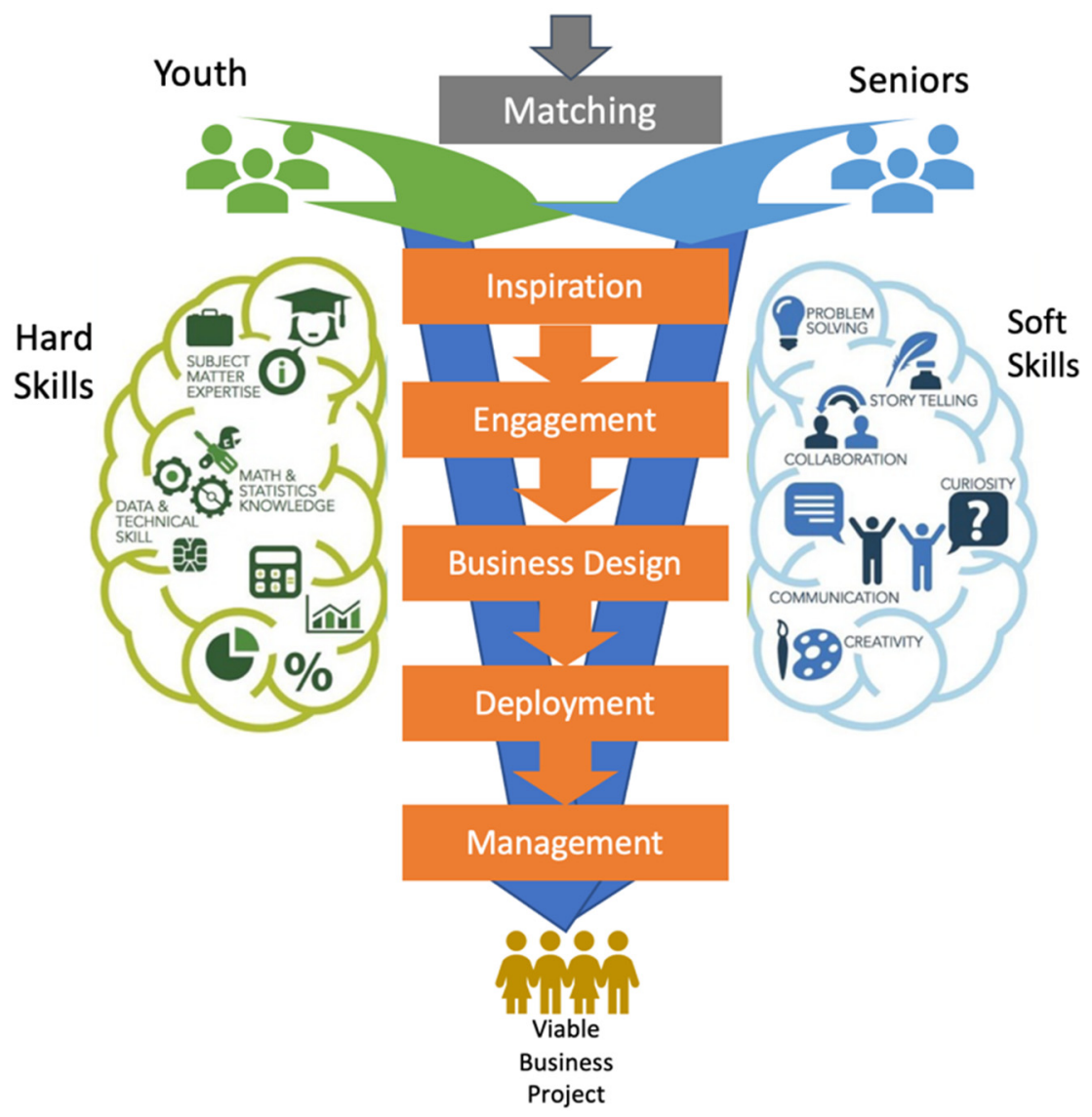

Figure 3. Overall approach of the training methodology. (Source: Designed by authors).

Given the diversity of personal profiles-professional, socioeconomic, educational, etc.-and the broad scope of general (mainly entrepreneurship-oriented) and specific (focused on a given sustainability challenge), the scope of the skills to be worked on can be very broad and, probably, discouraging and unmanageable. Thus, the designers opted for basic tool providing great flexibility to the learning and training experience: the "knowledge pill". The "knowledge pill" is basically a set of learning contents developed with a unique structure and including the most relevant issues related to a given topic considered useful to acquire certain skills. A set of knowledge pills (named "pills" from now on) can be grouped into a subject, and a set of subjects make up a training package adapted to a specific intergenerational program. This means that all the pills listed further need not be included in a specific training program adapted to a group's profile. Therefore, this teaching approach is very useful for a first contact with a knowledge field, creates concern and motivation to broaden knowledge, if necessary, and provides a great flexibility for time management.

Each pill should comply with the following requisites:

- Its contents should be designed for a 2-4-h learning session, although, if needed, can be linked to other pills with complementary contents.

- Its structure should include the following elements:

Title;

Brief description and justification;

Expected learning objectives and related topics;

Basic concepts and technical terms;

Suggested activities and active learning methods (open discussions, case analysis, challenges, problems, role-playing, simulation, etc.) either for the whole group or in separate teams; 
References (academic literature, online resources, and multimedia).

- The pill is an input for the instructor to develop the specific content and how it will be delivered to a specific group or project. This adaptive feature is considered crucial to broaden the methodology's scope of application.

Thus, as more and more pills are added through time, the whole set of pills make up a "toolbox" providing the learning materials and references needed to design, or redesign, any training program.

At this point of the research, the third research question is answered:

- Q3: Which hard and soft skills should be developed and in what stage of the business process?

According to the proposed methodology, the skills to be included in the training for the two groups are shown in Table 1. It includes the technical knowledge that entrepreneurs should acquire and the personal and interpersonal skills they should develop throughout the process of creating a company. To facilitate the temporary programming of the training, they are grouped into different modules corresponding to each stage of the entrepreneurial process. However, since entrepreneurship, as shown in Figure 2, is a continuous back and forth process, all the skills mentioned have a cumulative nature; that is, once the entrepreneur acquires one, it can be applied and improved through practice.

Table 1. Hard and soft skills.

\begin{tabular}{|c|c|c|}
\hline $\begin{array}{c}\text { Phase and } \\
\text { Learning Goal }\end{array}$ & Hard Skills & Soft Skills \\
\hline $\begin{array}{l}\text { INSPIRATION } \\
\text { "Is Intergenerational } \\
\text { entrepreneurship a solution to } \\
\text { address my future?" }\end{array}$ & $\begin{array}{l}\text { Professional technical competences } \\
\text { "What am I good at?" }\end{array}$ & $\begin{array}{c}\text { Motivation: "Why do I want to start a } \\
\text { business?" } \\
\text { Self-confidence } \\
\text { Cross-age interviews about strengths and } \\
\text { challenges * }\end{array}$ \\
\hline $\begin{array}{c}\text { ENGAGEMENT } \\
\text { "Do I have the knowledge, skills, } \\
\text { and attitudes needed to shape a } \\
\text { business idea?" }\end{array}$ & $\begin{array}{c}\text { Canvas } \\
\text { Design thinking } \\
\text { Lean Start-up } \\
\text { Agile } \\
\text { Collaborative tools } \\
\text { The viewpoint of sustainability } \\
\text { Environmental analysis (General and } \\
\text { Specific) }\end{array}$ & $\begin{array}{c}\text { Tribal leadership team building * } \\
\text { Emotional intelligence } \\
\text { Business acumen } \\
\text { Intergenerational team building for working as } \\
\text { a team } \\
\text { Creativity (Problem solving) and Creative } \\
\text { thinking } \\
\text { Detect market opportunities and cause-effect } \\
\text { dynamics } \\
\text { Communication and persuasion } \\
\text { Risk management } \\
\text { Time management }\end{array}$ \\
\hline
\end{tabular}

\section{SWOT Analysis}

Methods to evaluate business ideas Market research (the overall market, the targeted segments, the competition,) Business Model Design and Strategy

BUSINESS DESIGN

"Do I have the practical abilities to create a viable business project?" formulation (Business strategy and value proposition modelling)

Product/Service development

Industrial and intellectual protection Cost-benefit analysis Project management

Marketing and sales strategy Operations strategy Business Plan edition
Leadership

Team building and Group-work Networking and embedding ability Ability to overcome external constraints Resilience

Creative Information search Effective presentations Story telling Writing reports Negotiation

Respecting differences/managing conflict * 
Table 1. Cont.

\begin{tabular}{|c|c|c|}
\hline $\begin{array}{c}\text { Phase and } \\
\text { Learning Goal }\end{array}$ & Hard Skills & Soft Skills \\
\hline $\begin{array}{c}\text { DEPLOYMENT } \\
\text { "Do I have the practical abilities to } \\
\text { start a viable business project?" }\end{array}$ & $\begin{array}{c}\text { Financial analysis (break-even, turnover, } \\
\text { KPI, etc.) } \\
\text { Outsourcing } \\
\text { Understanding financial statements } \\
\text { ICT solutions } \\
\text { Back Office management (people, } \\
\text { administrative issues) } \\
\text { Entry strategy: when (time to market) } \\
\text { and how (start-up, acquisition, } \\
\text { franchising, etc.) } \\
\text { Financial strategy: personal funding, } \\
\text { banks, public financing, subsidies, } \\
\text { business angels, crowdfunding, etc. } \\
\text { Legal and tax issues }\end{array}$ & $\begin{array}{c}\text { Resourcefulness and ability to cope with } \\
\text { unexpected situations } \\
\text { Need of achievement and stamina } \\
\text { Conflict resolution } \\
\text { Share learnings * }\end{array}$ \\
\hline $\begin{array}{l}\text { MANAGEMENT } \\
\text { "Do I know how to create value } \\
\text { through time with my project?" }\end{array}$ & $\begin{array}{c}\text { Goal orientation (SMART) } \\
\text { Scenario analysis } \\
\text { Strategic transformation } \\
\text { Licensing rights, sales of patents and } \\
\text { franchising. } \\
\text { IPO (initial public offering) } \\
\text { Next generation } \\
\text { Buy out-Sell out }\end{array}$ & $\begin{array}{l}\text { Knowledge management } \\
\text { Flexibility and multi-skill capacity to respond } \\
\text { to unexpected events } \\
\text { Strategic competence }\end{array}$ \\
\hline
\end{tabular}

* These skills are aimed at reinforcing intergenerational relationships.

The implementation of this training methodology requires the design of a panoply of resources and tools, so the would-be entrepreneurs acquire the skills they need. These means can be classified into different categories:

- A team of trainers (teachers and specialists) and mentors or facilitators providing the knowledge and the expertise required for the teams to acquire the skills they need throughout the whole itinerary;

- A road map to adapt knowledge acquisition to the process of sustainable business venturing following the inventory of skills presented above;

- A template design to develop teaching materials under the same format and structure to facilitate content coordination and homogeneity of design.

Figure 4 depicts the basic framework for developing the instrumental materials and infrastructures needed to carry out the intergenerational projects.

The results are expected to serve as a guide for intergenerational entrepreneurship projects that aim to success considering the complementarities and needs each population have. 


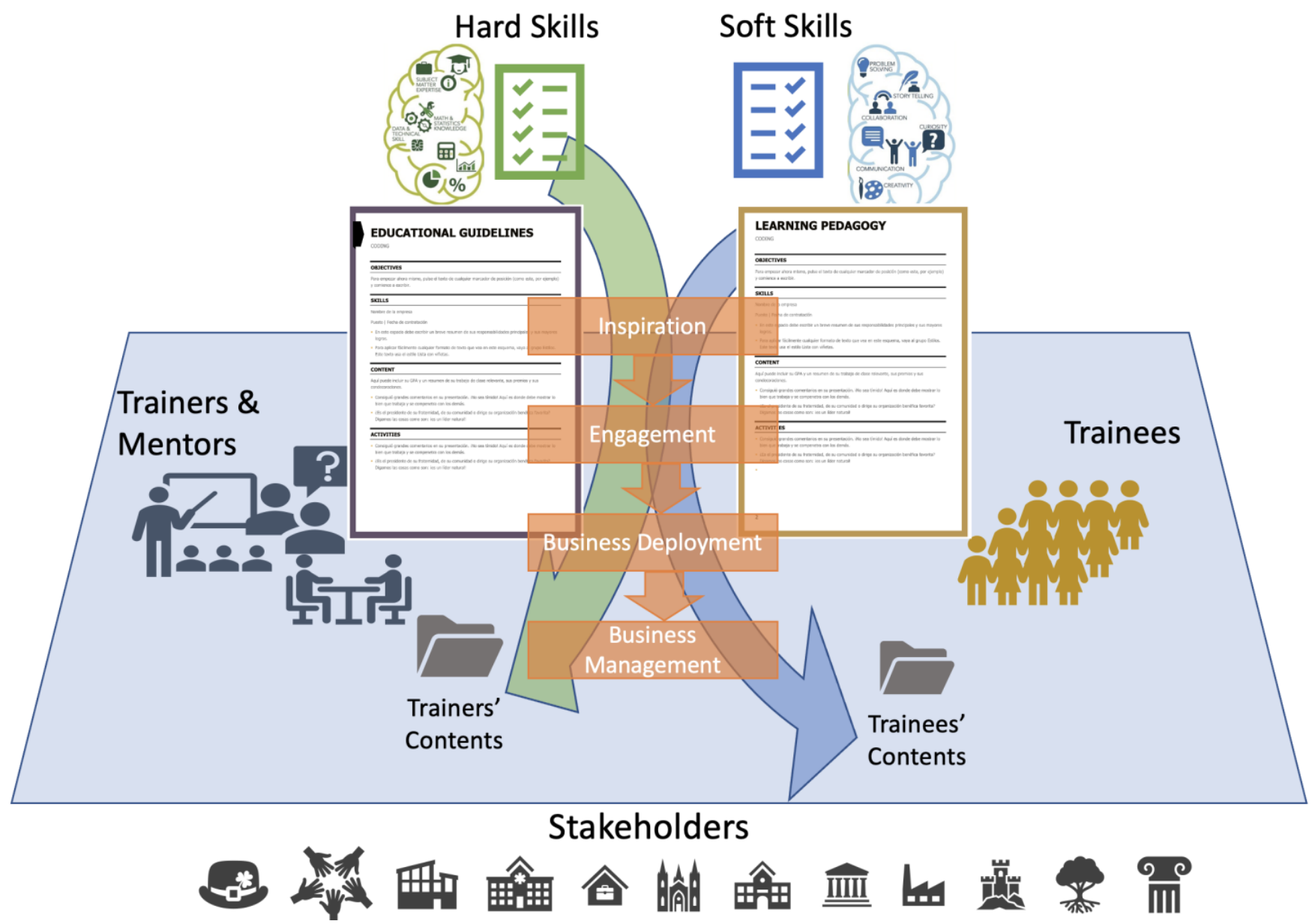

Figure 4. Institutional support and resource requirements. (Source: Designed by authors).

\section{Conclusions and Discussion}

Sustainable intergenerational entrepreneurship is a very narrow niche in the field of entrepreneurship with a high potential to generate social and economic value coinciding with Dean and McMullen, Cohen and Winn, and Rodriguez-Moreno's assessments of sustainable entrepreneurship [4-6]. This phenomenon may happen spontaneously, as a group of young and senior people share a common personal and technical background. However, prejudices and flaws in communication make it very unusual and fragile in most situations, as indicated by Perez-Encinas et al. and Baschiera et al. [22,34]. So, what we call "stakeholders" are a key element to approach its full potential. They are a set of collaborating institutions playing different roles along the process, in particular NGOs specialized in senior people and higher education institutions playing a key role. Other institutions focusing on sustainability, circular economy, the environment, and the business community would also be important stakeholders.

Cooperation between young and senior entrepreneurs depends upon the successful conviction and training of both generational groups along an active learning and interactive process $[62,63]$ with two main overlapping phases-team matching and entrepreneurial learning-aimed at fostering the long-term compromise between "project holders" and "skill holders".

The matching phase is a crucial part of the process of building the promoter team between young people and seniors as Faham [43,44] and TIGcRE [45] have suggested. In this phase, it is possible to count on the support or collaboration of mentors, as Walmsey and Nabi and Jordan and Sorell $[37,38]$ indicated, or other stakeholders who can accompany the entrepreneurs throughout the business process. It should begin by identifying the 
complementary aspects between the participants and should be oriented towards the objective of the common project. To promote mutual interests and compromise, one way may be to integrate the matching phase in the initial part of the training, via activities allowing them to get to know each other and align to collaborate in the development of the business project [62]; another option may come from the use of computerized matching systems and tools facilitating mutual awareness [46], team building, and sharing the knowledge, skills, and interests of each party to generate complementary business teams and even with potential mentors.

The entrepreneurial learning phase consists of a five-step progressive itineraryinspiration, engagement, business design, deployment, and management-based on Ndou, Secundo, Schiuma, and Passiante [56], each of them responding to a learning goal to be achieved with a specific set of hard and soft skills which, on a cumulative basis, complete the professional skills of the sustainable intergenerational entrepreneur all the way from the personal decision to become an entrepreneur to the manager of an ongoing successful business. Since the supporting training resources (professors, mentors, and specialists acting throughout a wide time lapse) provided by the stakeholders may involve a certain number of people, a structured training package in sustainable entrepreneurship should be designed, encompassing technical and behavioral aspects, networking, and pitching, amongst other contents proposed above. The first limitation identified in this study appears in the matching phase. In this early phase, it is crucial to count on the support specialists in the group dynamics related to generational gaps, that help young and senior entrepreneurs identify their complementary aspects.

Another one relies on the need to conduct a broad field test of the proposed methodology following the approach and skills contents to provide participants with the technical, intellectual, and social levers needed to succeed. Moreover, we acknowledge the convenience of extending this study to different population groups and different activities (life quality, education, environmental impact, etc.) and in different local, national, and international contexts with young and senior entrepreneurs.

The learning materials developed for the project consist of a set of educational guidelines for the trainers and mentors under the format of "knowledge pills" with a common structure and a corresponding set of learning contents for the prospective entrepreneurs. As more and more pills are developed through time, the whole set of pills make up a "toolbox" providing the learning materials and references needed to design, or redesign, any training program.

Author Contributions: Conceptualization, I.d.P., A.P.-E., B.S., and Y.B.; methodology, A.P.-E., I.d.P., Y.B., and B.S.; formal analysis, I.d.P., and A.P.-E.; investigation, I.d.P., B.S., A.P.-E., and Y.B.; data curation, I.d.P., Y.B., and B.S.; writing-original draft preparation, A.P.-E.; writing-review and editing, A.P.-E., I.d.P., B.S., and Y.B. All authors have read and agreed to the published version of the manuscript.

Funding: This research was funded by IVI project (2018-1-FR01-KA204-047946). Erasmus+ Key Action 204, funded with support from the European Commission. This publication reflects the views only of the author, and the Commission cannot be held responsible for any use which may be made of the information contained therein.

Institutional Review Board Statement: Not applicable.

Informed Consent Statement: Not applicable.

Data Availability Statement: Full focus group reports can be provided upon request, including participants' consent.

Acknowledgments: The authors, the partners of the IVI project and, especially Camila Nieto-Mejía and Miguel Angoitia for their valuable support in the whole process.

Conflicts of Interest: The authors declare no conflict of interest. The funders had no role in the design of the study; in the collection, analyses, or interpretation of data; in the writing of the manuscript, or in the decision to publish the results. 


\section{References}

1. Brundtland, G.H. Report of the World Commission on Environment and Development: "Our Common Future"; UN: New York, NY, USA, 1987.

2. Leggewie, C.; Welzer, H. Another "Great Transformation"? Social and cultural consequences of climate change. J. Renew. Sustain. Energy 2010, 2, 031009. [CrossRef]

3. Verner, D. (Ed.) Reducing Poverty, Protecting Livelihoods, and Building Assets in a Changing Climate: Social Implications of Climate Change for Latin America and the Caribbean; World Bank Publications: Washington, DC, USA, 2010.

4. Dean, T.J.; McMullen, J.S. Toward a theory of sustainable entrepreneurship: Reducing environmental degradation through entrepreneurial action. J. Bus. Ventur. 2007, 22, 50-76. [CrossRef]

5. Cohen, B.; Winn, M.I. Market imperfections, opportunity and sustainable entrepreneurship. J. Bus. Ventur. 2007, 22, 29-49. [CrossRef]

6. Rodríguez-Moreno, D.C. Emprendimiento sostenible, significado y dimensiones (Sustainable entrepreneurship, meaning and dimensions). Katharsis Rev. Cienc. Soc. 2016, 21, 449-479. [CrossRef]

7. Arzeni, S.; Pellegrin, J.P. Entrepreneurship and local development. OECD Obs. 1997, $204,23$.

8. Naudé, W. Entrepreneurship and Economic Development: Theory, Evidence and Policy; IZA Discussion Paper; IZA: Bonn, Germany, 2013; p. 7507.

9. Laborde, M.N.; Veiga, L. Emprendimiento y desarrollo económico. Rev. Antig. Alumnos IEEM 2010, $13,84-85$.

10. Luck, F.; Kraus, S.; Bouncken, R. Senior entrepreneurship: Definitions and underlying theories. Int. J. Bus. Res. 2014, 14, 209-215. [CrossRef]

11. Kautonen, T.; Kibler, E.; Minniti, M. Late-career entrepreneurship, income and quality of life. J. Bus. Ventur. 2017, 32, 318-333. [CrossRef]

12. Lewis, K.V.; Walker, E.A. Self-employment: Policy panacea for an ageing population? Small Enterp. Res. 2011, 18, 143-151. [CrossRef]

13. Backman, M.; Karlsson, C.; Kekezi, O. Introduction to the Handbook of Research on Entrepreneurship and Aging. In Handbook of Research on Entrepreneurship and Aging; Edward Elgar Publishing: Cheltenham, UK, 2019; pp. 1-21. [CrossRef]

14. Matos, C.; Amaral, M.; Baptista, R. Senior Entrepreneurship: A Selective Review and a Research Agenda. Found. Trends Entrep. 2018, 14, 427-554. [CrossRef]

15. Isele, E.; Rogoff, E.G. Senior Entrepreneurship: The New Normal. Public Policy Aging Rep. 2014, 24, 141-147. [CrossRef]

16. Soto-Simeone, A.; Kautonen, T. Senior entrepreneurship following unemployment: A social identity theory perspective. Rev. Manag. Sci. 2020, 15, 1683-1706. [CrossRef]

17. Figueiredo, E.; Paiva, T. Senior entrepreneurship and qualified senior unemployment: The case of the Portuguese Northern region. J. Small Bus. Enterp. Dev. 2018, 26, 342-362. [CrossRef]

18. Stypinska, J. The Enterprising Self: A Panacea for all or New Fictitious Social Role for Older Adults? The Analysis of European Polices for Senior Entrepreneurship. J. Popul. Ageing 2018, 11, 43-65. [CrossRef]

19. Saiz-Álvarez, J.M.; Coduras-Martínez, A. Territorial maps of senior entrepreneurship: A multidimensional analysis based on GEM data. In Entrepreneurship and Family Business Vitality; Springer: Cham, Switzerland, 2020; pp. 133-150. [CrossRef]

20. Mouraviev, N.; Avramenko, A. Senior Entrepreneurship: Ageing, Entrepreneurial Identity, Behaviour and Challenges. In Entrepreneurship for Deprived Communities; Emerald Publishing Limited: Bingley, UK, 2020; pp. 67-93. [CrossRef]

21. Pilková, A.; Rehák, J. Regional aspects of inclusive entrepreneurship of seniors in Europe. Soc. Econ. 2017, 39, 49-64. [CrossRef]

22. Perez-Encinas, A.; Bueno, Y.; Santos, B.; Nieto-Mejia, C. Are There Differences and Complementarities between Senior and Young Entrepreneurs? An Intergenerational Perspective. Sustainability 2021, 13, 5202. [CrossRef]

23. Drăgușin, M.; Sîrbu, M.O.; Grosu, R.M.; Iosif, A.E. Synergies of Longevity/Silver Economy and Senior Entrepreneurship for a Sustainable Society. The Case of Romania. In Building Engagement for Sustainable Development; Springer Gabler: Wiesbaden, Germany, 2019. [CrossRef]

24. Maritz, A. Senior entrepreneurship in Australia: An exploratory approach. Int. J. Organ. Innov. 2015, 7, 6-23.

25. Pinto, T.A.; Marreel, I.; Hatton-Yeo, A. Guía de Ideas para la Planificación y Aplicación de Proyectos Intergeneracionales (Guide of Ideas for Planning and Implementing Intergenerational Projects); European Educational Research Association: Berlin, Germany, 2009; ISBN 978-989-8283-01-6.

26. Mitrofanenko, T. Intergenerational Practice: An Approach to Implementing Sustainable Development and Environmental Justice. In Women and Children as Victims and Offenders: Background, Prevention, Reintegration; Springer: Cham, Switzerland, 2016; pp. 721-743. [CrossRef]

27. United Nations. Report of the Second World Assembly on Ageing", Madrid, 8-12 April; UN: New York, NY, USA, 2002.

28. Saeed, S.; Muffatto, M.; Yousafzai, S. Exploring intergenerational influence on entrepreneurial intention: The mediating role of perceived desirability and perceived feasibility. Int. J. Entrep. Innov. Manag. 2004, 18, 134-153. [CrossRef]

29. Ferrand-Latorre, S.; Velilla, J. La Transmisión Intergeneracional de la Actividad Emprendedora en las Familias Españolas. Munich Personal RePEc Archive (MPRA) Paper No. 83573. 2018. Available online: https://mpra.ub.uni-muenchen.de/83601/ (accessed on 25 July 2021).

30. Iqbal, J.; Kousar, S.; Hameed, W.U. Antecedents of Sustainable Social Entrepreneurship Initiatives in Pakistan and Outcomes: Collaboration between Quadruple Helix Sectors. Sustainability 2018, 10, 4539. [CrossRef] 
31. Peris-Ortiz, M.; Ferreira, J.J.; Farinha, L.; Fernandes, N.O. Introduction to Multiple Helix Ecosystems for Sustainable Competitiveness. In Multiple Helix Ecosystems for Sustainable Competitiveness. Innovation, Technology, and Knowledge Management; Peris-Ortiz, M., Ferreira, J., Farinha, L., Fernandes, N., Eds.; Springer: Cham, Switzerland, 2016. [CrossRef]

32. Dana, L.P.; Gurau, C.; Light, I.; Muhammad, N. Family, Community, and Ethnic Capital as Entrepreneurial Resources: Toward an Integrated Model. J. Small Bus. Manag. 2019, 58, 1003-1029. [CrossRef]

33. Rashid, L. Entrepreneurship Education and Sustainable Development Goals: A literature Review and a Closer Look at Fragile States and Technology-Enabled Approaches. Sustainability 2019, 11, 5343. [CrossRef]

34. Baschiera, B.; Santini, S.; Socci, M. Intergenerational entrepreneurship education: Older entrepreneurs reducing youngsters' social and work disengagement. Probl. Educ. 21st Century 2018, 76, 7-20. [CrossRef]

35. Alsaleh, S.; Nayak, R.; Xu, Y.; Chen, L. Improving matching process in social network using implicit and explicit user infor-mation. In Web Technologies and Applications, Proceedings of the 13th Asia-Pacific Web Conference, Beijing China 18 April 2011; Du, X., Fan, W., Wang, J., Peng, Z., Sharaf, M.A., Eds.; Lecture Notes in Computer Science; Springer: New York, NY, USA, 2011; Volume 6612, pp. 313-320.

36. Kutty, S.; Nayak, R.; Chen, L. A people-to-people matching system using graph mining techniques. World Wide Web 2014, 17, 311-349. [CrossRef]

37. Walmsley, A.; Nabi, G. Mentoring Senior Entrepreneurs. In Entrepreneurship Education. Contributions to Management Science; Sawang, S., Ed.; Springer: Cham, Switzerland, 2020; pp. 85-100. [CrossRef]

38. Jordan, J.; Sorell, M. Why Reverse Mentoring Works and How to Do It Right; Harvard Business Review: Brighton, MA, USA, 2019.

39. Milam, J. Matching Angel Investors with Entrepreneurs; Espacenet: Alexandria, VA, USA, 2002.

40. Polzin, F.; Sanders, M.; Stavlöt, U. Do investors and entrepreneurs match? -Evidence from The Netherlands and Sweden. Technol. Forecast. Soc. Chang. 2018, 127, 112-126. [CrossRef]

41. Lasso, S.V.; Mainardes, E.; Motoki, F.Y.S. Types of Technological Entrepreneurs: A Study in a Large Emerging Economy. J. Knowl. Econ. 2018, 9, 378-401. [CrossRef]

42. Cipollone, A.; Giordani, P.E. Entrepreneurs meet financiers: Evidence from the business angel market. J. Bus. Ventur. 2019, 34, 105913. [CrossRef]

43. Faham, J. The Instrumentation of the "Entrepreneurial Discovery" Process of Research and Innovation Smart Specialisation Strategies (RIS3): Proposition of a Collaborative Platform and a Matching Methodology for "Regional Entrepreneurs" in Order to Support Interactions within the Intermediary Zones of the Regional Innovation System of Nouvelle-Aquitaine. Ph.D. Thesis, École Doctorale des Sciences Physiques et de L'ingénieur, Université de Bordeaux, Bordeaux, France, 2018.

44. Faham, J.; Daniel, M.; Legardeur, J. Toward a Matching Approach to Support CBM (Collaborative Business Model) Processes Between Regional Entrepreneurs within the RIS3 Policy. In Advances in Production Management Systems, Initiatives for a Sustainable World. APMS 2016. IFIP Advances in Information and Communication Technology; Nääs, I., Vendrametto, O., Mendes, J., Goncalves, R., Terra, M., von Cieminski, G., Kiritsis, D., Eds.; Springer: Cham, Switzerland, 2016; p. 488. [CrossRef]

45. TIGcRE. Available online: https://www.tigcre.org (accessed on 12 March 2021).

46. Intelli7. Available online: https:/ / www.intelli7.com/ (accessed on 12 March 2021).

47. Kuratko, D.F. The Emergence of Entrepreneurship Education: Development, Trends, and Challenges. Entrep. Theory Pract. 2005, 29, 577-597. [CrossRef]

48. Volkmann, C. Entrepreneurial studies in higher education: Entrepreneurship studies-An ascending Academic Discipline in the Twenty-First Century. High. Educ. Eur. 2004, 29, 177-185. [CrossRef]

49. Kuratko, D.F. Entrepreneurship Education: Emerging Trends and Challenges for the 21st Century; Coleman Foundation White Paper Series for the U.S. Association of Small Business \& Entrepreneurship: Tokyo, Japan, 2003.

50. Hindle, K. Teaching Entrepreneurship at University: From the Wrong Building to the Right Philosophy. In Handbook of Research in Entrepreneurship Education; Edward Elgar Publishing: Cheltenham, UK, 2007; Volume 1, pp. 104-126.

51. Sirelkhatim, F.; Gangi, Y. Entrepreneurship education: A systematic literature review of curricula contents and teaching methods. Cogent Bus. Manag. 2015, 2, 1052034. [CrossRef]

52. McMullan, W.E.; Vesper, K. New Ventures and Small Business Innovation for Economic Growth. RED Manag 1987, 17, 3-13. [CrossRef]

53. Vesper, K.H.; Gartner, W.B. Measuring progress in entrepreneurship education. J. Bus. Ventur. 1997, 12, 403-421. [CrossRef]

54. Honig, B. Entrepreneurship Education: Toward a Model of Contingency-Based Business Planning. Acad. Manag. Learn. Educ. 2004, 3, 258-273. [CrossRef]

55. Morris, M.H.; Webb, J.W.; Fu, J.; Singhal, S. A Competency-Based Perspective on Entrepreneurship Education: Conceptual and Empirical Insights. J. Small Bus. Manag. 2013, 51, 352-369. [CrossRef]

56. Ndou, V.; Secundo, G.; Schiuma, G.; Passiante, G. Insights for Shaping Entrepreneurship Education: Evidence from the European Entrepreneurship Centers. Sustainability 2018, 10, 4323. [CrossRef]

57. Harmeling, S.S.; Sarasvathy, S.D. When Contingency is a Resource: Educating Entrepreneurs in the Balkans, the Bronx, and Beyond. Entrep. Theory Pract. 2013, 37, 713-744. [CrossRef]

58. Minniti, M.; Bygrave, W. A Dynamic Model of Entrepreneurial Learning. Entrep. Theory Pract. 2001, 25, 5-16. [CrossRef]

59. Cope, J.; Watts, G. Learning by doing-An exploration of experience, critical incidents and reflection in entrepreneurial learning. Int. J. Entrep. Behav. Res. 2000, 6, 104-124. [CrossRef] 
60. Klapper, R.; Tegtmeier, S. Innovating entrepreneurial pedagogy: Examples from France and Germany. J. Small Bus. Enterp. Dev. 2010, 17, 552-568. [CrossRef]

61. Ramoglou, S. Who is a 'non-entrepreneur'?: Taking the 'others' of entrepreneurship seriously. Int. Small Bus. J. Res. Entrep. 2011, 31, 432-453. [CrossRef]

62. Sarasvathy, S.D. Effectual reasoning in entrepreneurial decision making: Existence and bounds. Acad. Manag. Proc. 2001, 2001, D1-D6. [CrossRef]

63. Shepherd, D.A.; Williams, T.A.; Patzelt, H. Thinking about Entrepreneurial Decision Making: Review and research agenda. J. Manag. 2015, 41, 11-46. [CrossRef]

64. Chandler, G.N.; DeTienne, D.R.; McKelvie, A.; Mumford, T.V. Causation and effectuation processes: A validation study. J. Bus. Ventur. 2011, 26, 375-390. [CrossRef]

65. Ries, E. El Método Lean Startup: Cómo Crear Empresas de Éxito Utilizando la Innovación Continua; Deusto: Bilbao, Spain, 2012.

66. Azim, M.T.; Al-Kahtani, A.H. Entrepreneurship Education and Training: A Survey of Literature. Life Sci. J. 2014, 11, 127-135.

67. Bacigalupo, M.; Kampylis, P.; Punie, Y.; Van den Brande, G. EntreComp: The Entrepreneurship Competence Framework; EUR 27939 EN; Publication Office of the European Union: Luxembourg, 2016. [CrossRef]

68. Jones, C. Entrepreneurship education: Revisiting our role and its purpose. J. Small Bus. Enterp. Dev. 2010, 17, 500-513. [CrossRef]

69. Corbett, A.C. Experiential Learning within the Process of Opportunity Identification and Exploitation. Entrep. Theory Pract. 2005, 29, 473-491. [CrossRef]

70. Chang, J.; Rieple, A. Assessing students' entrepreneurial skills development in live projects. J. Small Bus. Enterp. Dev. 2013, 20, 225-241. [CrossRef]

71. Heinonen, J.; Poikkijoki, S. An entrepreneurial-directed approach to entrepreneurship education: Mission impossible? J. Manag. Dev. 2006, 25, 80-94. [CrossRef]

72. Fayolle, A.; Gailly, B. The Impact of Entrepreneurship Education on Entrepreneurial Attitudes and Intention: Hysteresis and Persistence. J. Small Bus. Manag. 2015, 53, 75-93. [CrossRef]

73. Piperopoulos, P.; Dimov, D. Burst Bubbles or Build Steam? Entrepreneurship Education, Entrepreneurial Self-Efficacy, and Entrepreneurial Intentions. J. Small Bus. Manag. 2015, 53, 970-985. [CrossRef]

74. Fayolle, A.; Gailly, B.; Lassas-Clerc, N. Assessing the impact of entrepreneurship education programmes: A new methodology. J. Eur. Ind. Train. 2006, 30, 701-720. [CrossRef]

75. Chell, E. Review of skill and the entrepreneurial process. Int. J. Entrep. Behav. Res. 2013, 19, 6-31. [CrossRef]

76. Amabile, T.M. Creatividad e Innovación en las Organizaciones (Creativity and Innovation in Organizations); Harvard Business School: Boston, MA, USA, 1996; Volume 305, p. S11.

77. Ardichvili, A.; Cardozo, R.; Ray, S. A theory of entrepreneurial opportunity identification and development. J. Bus. Ventur. 2013, 18, 105-123. [CrossRef]

78. Locke, E.E.; Baum, J.R. Entrepreneurial motivation. In The Psychology of Entrepreneurhip; Baum, J.R., Frese, M., Baron, R., Eds.; Robert Erlbaum: Mahwah, NJ, USA; London, UK, 2007; pp. 93-112.

79. Sternberg, R.J. Wisdom, Intelligence, and Creativity Synthesized; Cambridge University Press: Cambridge, UK; New York, NY, USA, 2003.

80. Baron, R.; Markman, G.D. Beyond social capital: The role of entrepreneurs' social competence in their financial success. J. Bus. Ventur. 2003, 18, 41-60. [CrossRef]

81. Witt, U. Imagination and leadership - The neglected dimension of an evolutionary theory of the firm. J. Econ. Behav. Organ. 1998, 35, 161-177. [CrossRef]

82. Shane, S. Prior Knowledge and the Discovery of Entrepreneurial Opportunities. Organ. Sci. 2000, 11, 448-469. [CrossRef]

83. Shane, S. A General Theory of Entrepreneurship: The Individual-Opportunity Nexus; Edward Elgar Publishing: Cheltenham, UK, 2003.

84. Stevenson, H.H.; Roberts, M.J.; Grousbeck, H.I. New Business Ventures and the Entrepreneur; Irwin: Homewood, IL, USA, 1985.

85. Stevenson, H.H.; Roberts, M.J.; Grousbeck, H.I. New Business Ventures and the Entrepreneur, 3rd ed.; Irwin: Homewood, IL, USA, 1989.

86. Timmons, J.A. The Entrepreneurial Mind; Brick House Publishing: Andover, MA, USA, 1989.

87. Harper, D. Entrepreneurship and the Market Process; Routledge: London, UK, 1996.

88. Miner, J.B.; Raju, N.S. Risk Propensity Differences between Managers and Entrepreneurs and Between Low- and High-Growth Entrepreneurs: A Reply in a More Conservative Vein. J. Appl. Psychol. 2004, 89, 3-13. [CrossRef]

89. Chell, E.; Baines, S. Networking, entrepreneurship and microbusiness behaviour. Entrep. Reg. Dev. 2000, 12, 195-215. [CrossRef]

90. Bandura, A. Social cognitive theory of personality. In The Coherence of Personality: Social Cognitive Biases in Consistency, Variability and Organization; Cerzone, D., Shoda, Y., Eds.; Guilford: New York, NY, USA, 1999; pp. 185-241.

91. Chell, E. The Entrepreneurial Personality: A Social Construction, 2nd ed.; Routledge: London, UK; New York, NY, USA, 2008.

92. Peris, L.M.; Ripollés, M.; Pérez, A.B. Una propuesta didáctica para la creación de microempresas. La Escuela para Emprender. Rev. Int. Organ. 2020, 24, 273-297. [CrossRef]

93. Shapero, A. The displaced, uncomfortable entrepreneur. Psychol. Today 1975, 9, 83-88.

94. Jack, S.; Anderson, A. The effects of embeddedness on the entrepreneurial process. J. Bus. Ventur. 2002, 17, 467-487. [CrossRef]

95. Creswell, J.D. Research Design: Qualitative, Quantitative, and Mixed Methods Approaches; Sage Publications: Thousand Oaks, CA, USA, 2017. 
96. Breen, R.L. A Practical Guide to Focus-Group Research. J. Geogr. High. Educ. 2006, 30, 463-475. [CrossRef]

97. Javadian, G.; Dobratz, C.; Gupta, A.; Gupta, V.K.; Martin, J.A. Qualitative Research in Entrepreneurship Studies: A State-of-Science. J. Entrep. 2020, 29, 223-258. [CrossRef]

98. Queirós, A.; Faria, D.; Almeida, F. Strengths and limitations of qualitative and quantitative research methods. Eur. J. Educ. Stud. 2017, 3, 369-387.

99. Powell, R.A.; Single, H.M. Focus Groups. Int. J. Qual. Heal. Care 1996, 8, 499-504. [CrossRef] [PubMed]

100. Liamputtong, P. Focus Group Methodology: Principle and Practice; Sage Publications: London, UK, 2011. [CrossRef]

101. Ritchie, J.; Spencer, L. Qualitative data analysis for applied policy research. Anal. Qual. Data 1994, $173,194$.

102. Srivastava, A.; Thomson, S.B. Framework Analysis: A Qualitative Methodology for Applied Research. J. Adm. Gov. 2009, 4, 72-79. 